\title{
A FORMAÇÃO DA ATMOSFERATERRESTRE - HISTÓRIA EM QUADRINHOS A PARTIR DE CONTO DE ITALO CALVINO
}

\author{
Earth's atmosphere formation - Calvino's tale in comics
}

La formación de la atmósfera de la Tierra - Cuento de Italo Calvino en cómics

\author{
Erika Collischonn* \\ *Doutora em Geografia pela Universidade de Santa Catarina \\ - ecollischonn@gmail.com
}

\begin{abstract}
Recebido em 20/10/2019. Aceito para publicação em 20/10/2019.
Versão online publicada em 10/11/2019 (http://seer.ufrgs.br/paraonde)
\end{abstract}

\section{Resumo:}

A imaginação é fundamental na compreensão dos processos naturais. A partir do que aprendemos com colegas da literatura, sobre a fenomenologia da imaginação do filósofo Gaston Bachelard, temos feito uso da prosa e da poesia com professores de geografia em formação. Neste artigo relatamos uma prática realizada nas aulas de Climatologia no Curso de Licenciatura em Geografia, com o conto "Sem cores" do livro "As cosmicômicas" de Italo Calvino, que descreve a formação da atmosfera terrestre através de uma narrativa poética. A originalidade criativa deste conto envolve uma constante tensão entre termos técnicos e coloquiais, entre ciência e literatura, entre imaginação e realidade, que propicia encantamento. Dividimos a prática em diferentes momentos. Primeiro, apresentamos o autor, sua forma de escrita e o personagem criado para narrar a história. Em seguida, propusemos uma leitura individual do texto e o destaque das imagens criadas pelo autor para descrever os processos e as características da atmosfera terrestre. Depois, provocamos os alunos a lerem extratos que mais gostaram no conto e explicarem as razões da escolha. Como atividade avaliativa propusemos a apresentação da narrativa em quadrinhos. O resultado nos mostrou que há a possibilidade de aprender por meios que possibilitem o encantamento e a imaginação, antes da definição de conceitos.

Palavras-chave: : Formação da atmosfera.Imaginação. Quadrinhos.

\begin{abstract}
:
Imagination is fundamental in understanding natural processes. Based on what we learn from Bachelard's "Phenomenology of imagination" with literacy teachers, we have made use of prose and poetry in the academic education of geography teachers. In this article we report a practice carried out in Climatology classes, with the tale "Without Colors" from the book "Cosmicomics" by Italo Calvino, which describes the formation of the earth's atmosphere through a poetic narrative. The creative originality of this tale involves a constant tension between technical and colloquial terms, between science and literature, between imagination and reality, which favors enchantment. We divide the practice at different times. First, we introduce the author, his language, and the character created to tell the story. We then suggest an individual reading of the tale to mark the images created by the author to describe the processes and characteristics of the earliest earth's atmosphere. Then we ask students to read those extracts from the text they liked best and to explain the reasons for this preference. As an evaluative activity we proposed that students present the narrative in comics. The result has shown us that there is a possibility of learning otherwise, in a way that enables enchantment and imagination, before defining concepts.
\end{abstract}

Key-words:Earthatmosphere formation. Imagination. Comics. 


\begin{abstract}
Resumen:
La imaginación es fundamental para comprender los procesos naturales. En base a lo que hemos aprendido sobre la "Fenomenología de la imaginación" de Bachelard de los profesores de literatura, hemos utilizado la prosa y la poesía en la educación académica de los maestros de geografía. En este artículo informamos una práctica llevada a cabo en las clases de Climatología, con el cuento "Sin colores" del libro "Las Cosmicómicas" de Italo Calvino, que describe la formación de la atmósfera de la Tierra a través de una narrativa poética. La originalidad creativa de este cuento implica una tensión constante entre términos técnicos y coloquiales, entre ciencia y literatura, entre imaginación y realidad, lo que favorece el encanto. Dividimos la práctica en diferentes momentos. Primero, presentamos al autor, su escritura y el personaje que creó para contar la historia. Luego sugerimos una lectura individual del cuento para marcar las imágenes creadas por el autor para describir los procesos y características de la atmósfera terrestre más antigua. Luego les pedimos a los estudiantes que lean esos extractos del cuento que más les gusta y que expliquen los motivos de esta elección. Como actividad evaluativa, propusimos que los estudiantes presenten la narrativa en cómics. El resultado nos ha demostrado que existe la posibilidad de aprender de otras maneras, por ejemplo, un modo que permita el encanto y la imaginación, antes de la definición de conceptos.
\end{abstract}

Palabras-clave:Formación de la atmósfera terrestre. Imaginación. Historietas.

\title{
1 Introdução
}

Nos cursos de climatologia para a formação de professores de geografia a unidade "Atmosfera terrestre - composição e estrutura" é uma das primeiras do plano de disciplina. A subunidade "Composição da atmosfera" é maçante, quando desvinculada da relação como a formação da atmosfera e quando os processos cotidianos de interação humana com esta atmosfera não são ilustrados. Normalmente, o que acaba acontecendo no processo de ensino-aprendizagem é uma memorização de constituintes, camadas e processos da atmosfera, que não ganham significância no mundo subjetivoe, por isso, não são internalizados pelos sujeitos.

Corriqueiramente a formação e composição da atmosfera terrestre é trabalhada somente com base em livro texto, do qual, por meio de leitura, extraem-se conceitos para delimitar o conhecimento. Ainda que se considere tal prática apropriada ao fazer pedagógico, expõe-se neste artigo, uma outra maneira de aprendizagem por intermédio da literatura e da ilustração.

No caso, a proposição foi um conto do livro "As cosmicômicas" do escritor Italo Calvino. Neste livro, o escritor narra de uma forma inusitada desde a expansão inicial do Universo até as primeiras formas de vida terrestre, trazendo, ao mesmo tempo, ideias simbólicas bem subjetivas. Os leitores, mesmo sem nunca terem lido outra obra de Ítalo Calvino, podem rapidamente captar a profundidade do conto; com reflexos em problemas sociais ou pessoais dos dias atuais. Apesar de escrever em prosa, seus contos têm a sutileza e as metáforas próprias da poesia.

O protagonista de "As cosmicômicas" é um personagem impronunciável, "Qfwfq", difícil de definir, porque dele se sabe apenas que é um ser mutante, que dá seu testemunho, com um relato fantástico, de cada etapa de evolução do universo. Ele existiu sob diferentes formas, estando já presente antes da grande explosão; portanto, participou da evolução, como partícula atômica, como célula ou como animal primitivo. Algumas vezes foi um participante desavisado, noutras provocou ou acelerou o processo, enquanto

ParaOnde!?, Porto Alegre, v.12 n.2, p.96-106, 2019. http://seer.ufrgs.br/paraonde Edição Especial - III Colóquio de Pesquisadores em Geografia Física Ensino de Geografia 
brincava, tropeçava, caía, se apaixonava. As relações que ele estabelece com os outros e o mundo, são familiares. "Qfwfq" sente e age como humano; até gênero pode-se identificar nele e nos seres que com ele convivem, mesmo que não se possa rotulá-los. Além disso, entre eles há pensamento antes de haver linguagem (VILAROUCA, 2010).

Cada conto do livro é desencadeado por um enunciado científico, ressaltado em itálico, que permite segundo Ferraz (2013, p.36) "a saída do mundo real e a entrada no mundo de "Qfwfq", no qual teremos acesso a suas lembranças de tempos remotos. A ciência é tomada como propulsora à capacidade imaginativa, como um dos múltiplos modos de se representar o cosmo.

O conto "As cores" na coletânea "As cosmicômicas" de Italo Calvino foi utilizado para propiciar uma compreensão mais encantada da teoria sobre a formação da atmosfera terrestre nas aulas de Climatologia, pensando também na ressonância desta prática no Ensino Fundamental e Médio.

\section{Um conto que já propicia um roteiro}

No conto "As cores", Calvino dá "voz àquilo que não tem voz", dá "um nome àquilo que ainda não tem nome", conforme escreve Ferraz (2005, p.20). Apesar de escrito em prosa contem as imagens da poesia, quando descreve, com genialidade, a formação da atmosfera terrestre. O conto repercute, não somente no que diz respeito aos processos cognitivos vinculados à racionalidade, mas também no mais íntimo, na condição humana.

Vejamos como "Qfwfq" descreve como era viver antes da existência da atmosfera. Por exemplo o vácuo é assim descrito: "Andava eu por milhas e milhas velocíssimo como se anda quando não existe ar de permeio" (CALVINO, 1992, p.51). A falta de cores é assim definida: "Nenhum contraste nítido, o branco inteiramente branco, se é que havia, estava no sol [...] negro inteiramente negro, não era nem o negror noturno, dado o grande número de estrelas sempre a vista." A não existência de água, ainda que já prenunciada, é assim descrita "jamais chegava-se a uma praia, porque os oceanos, os lagos, os rios, jaziam sabe-se lá onde sob a terra" (CALVINO, 1992, p. 51-52).

O narrador complementa ainda o relato desta experiência de viver na Terra, com suas camadas ainda em formação e sob uma radiação inclemente, com a seguintes palavras:

Os encontros eram raros. Éramos tão poucos. Para resistir ao ultravioleta era preciso contentar-se com pouco. [...] os meteoros: granizavam por todos os pontos do espaço, porque não havia a estratosfera contra a qual agora se chocam como se fosse um anteparo, nela se desintegrando. Depois o silêncio: não adiantava gritar! Sem o ar vibrando éramos todos mudos e surdos. E a temperatura? Nada em volta havia que pudesse conservar o calor. Com a noite vinha um frio de gelar. Por sorte a crosta terrestre escaldava debaixo de nós, com todos aqueles minerais em fusão, que se comprimiam nas vísceras do planeta; as noites eram curtas (como os dias: a Terra girava sobre si mesmo bem mais veloz que hoje). Eu dormia abraçado a uma rocha muito quentinha [...] Em meio a tantas coisas indispensáveis que nos faltava, bem pode compreender-se que a ausência de cores era um problema menor (CALVINO, 1992, p.52).

A partir deste preâmbulo se inicia a vivência de um novo tempo/espaço e a

ParaOnde!?, Porto Alegre, v.12 n.2, p.96-106, 2019. http://seer.ufrgs.br/paraonde Edição Especial - III Colóquio de Pesquisadores em Geografia Física Ensino de Geografia 
aventura amorosa com "Ayl". Com essa coadjuvante, que já estava presente anteriormente, mas lhe era imperceptível, o protagonista vivencia a solidificação da crosta, a formação da atmosfera terrestre e, ainda, os efeitos sensoriais destes processos: refração da luz, espessamento gasoso e pressão atmosférica, efeito da gravidade, o propagar do som, a formação dos oceanos, a investida da clorofila.

Levei as mãos aos ouvidos ensurdecidos, e naquele momento senti igualmente a necessidade de tapar o nariz e a boca para não aspirar a forte mistura de oxigênio e azoto que me circundava, porém mais forte que tudo foi o impulso de tapar os olhos que me pareciam explodir (CALVINO, 1992, p.58).

As figuras de linguagem usadas para descrever cada situação são magníficas e tudo acontece enquanto esses dois seres ("Qfwfq" e "Ayl") vão se conhecendo nas suas diferenças. Diferenças estas que para o narrador, ao mesmo tempo em que têm a magia do novo, do diverso, do lindo, também já trazem em si a incompatibilidade entre o protagonista e "Ayl".

Mas fui logo obrigado a reconhecer que Ayl e eu tínhamos gostos diferentes, para não dizer opostos: eu procurava um mundo diverso para além da pátina pálida que aprisionava todas as coisas e perscrutava o menor sinal, o mínimo indício (na verdade algo estava começando a mudar, em certos pontos a ausência de cores parecia percorrida por vislumbres cambiantes); Ayl , ao contrário, era um habitante feliz do silêncio que reina ali onde se excluem todas as vibrações, para ela tudo que tendia a romper a neutralidade visual era um destoamento estridente; para ali onde o cinza havia afogado ainda que o mais remoto desejo de ser algo além de cinza, somente ali é que a beleza começava (CALVINO, 1992, p.55).

E como em todos os demais contos de "As cosmicômicas" chega um momento em que os destinos desses seres apaixonados tomam rumos diferentes. Isto ocorre porque, efetivamente, a aproximação serviu mais para que o narrador conhecesse melhor a si mesmo e, ao mesmo tempo, se maravilhasse com o mundo novo que surgia.

A forma como o protagonista narra nos remete a algum avô ou avó contando uma história do passado. Como observou Vilarouca (2010, p. 365)

[...] participamos das histórias de Qfwfq com a mesma familiaridade experimentada em relação a uma história de um evento cotidiano. Nem estranhamos o fato de ele nos contar histórias que se produziram em milhares de anos e menos ainda o fato de ele estar presente nesse período.

Assim, considera-se que o texto já propicia um roteiro.

\section{Metodologia}

Para o desenvolvimento da atividade, primeiramente foi explicado a turma um pouco do universo literário de Italo Calvino e as características comuns que perpassam os contos agrupados em "As cosmicômicas".

A partir desta introdução, foi solicitada a leitura do conto para a aula seguinte, o destaque no texto dos recursos de que se utiliza Calvino na fala do narrador, para concretizar os enunciados científicos e descrever as diferentes etapas de formação da atmosfera terrestre e as características decorrentes.

ParaOnde!?, Porto Alegre, v.12 n.2, p.96-106, 2019. http://seer.ufrgs.br/paraonde Edição Especial - III Colóquio de Pesquisadores em Geografia Física Ensino de Geografia 
$\mathrm{Na}$ aula que se seguiu, os alunos deveriam ler em voz alta os trechos de que mais gostaram no texto. A participação, nesta etapa, ficou aquém do esperado, mas a professora aproveitou para mostrar o seu próprio encantamento com o conto, lendo e revelando as figuras de linguagem que há nele descritas, destacando que foram utilizados vocábulos, cujo significante não atinge diretamente o significado, mas as palavras e expressões são transfiguradas pela mediação do escritor que as reelabora justamente para aproximar o enunciado científico da vivência cotidiana. São exemplos: "mundo diverso para além da pátina pálida", "que se comprimiam nas vísceras do planeta", "vislumbres cambiantes", "matizes que ainda não haviam sido vistos".

Foram extraídas do texto, na sequencia, as figuras de linguagem que expressavam o que acontecia durante o processo de formação da atmosfera terrestre associando-as a conceitos que poderiam ser lidos no livro texto de climatologia, procurando fazer a leitura "técnica" do texto. Por fim, os estudantes foram provocados a darem vazão a uma leitura inspirada do texto que permitisse outras formas de representação deste conto, por exemplos, com imagens.

Assim, a partir do conto motivador foram propostos dois tipos de atividade avaliativa, explorando habilidades diferenciadas entre os estudantes: uma análise do texto destacando todos os trechos do texto que pudessem ser associados a elementos, características e processos da atmosfera terrestre que, em grande parte, constavam de outra forma no livro texto; ou a criação de uma história em quadrinhos a partir do conto de Calvino.

A grande maioria dos alunos optou pela análise do texto, que era com certeza a atividade com a qual estavam mais familiarizados no meio acadêmico. Por ser diferenciada, é que se dá destaque neste artigo a versão em história em quadrinhos criada a partir da leitura e interpretação do conto "Sem Cores". A transcrição da linguagem do conto para o desenho e alguns extratos da história serão apresentados na próxima seção.

\section{Resultados e discussão}

Ainda que se tivesse sugerido a criação de uma história em quadrinhos (HQ), não foram trabalhadas em aula técnicas de criação, representação e diagramação, nem se considerou o tempo necessário para o processo criativo em $\mathrm{HQ}$. A maioria dos estudantes entregaram a análise de texto conforme sugerido na semana seguinte; somente um estudante solicitou uma semana a mais para terminar sua história em quadrinhos.

Ainda que o roteiro da história já estivesse criado por Italo Calvino, não havia definição, sobre a forma que teriam os personagens, sobre a os quadros e sobre a sequencia em que seriam desenhados. Uma semana depois, o estudante Fabrício Vaz Rodrigues chegou com sua produção, uma História em Quadrinhos com 11páginas e 19 quadros (Rodrigues, 2015).

Conforme já foi escrito, "Qfwfq", o protagonista, é um personagem difícil de definir. Não vem nunca claramente dito quem era ou como era, mas somente que existia, que estava ali. Nosso ilustrador, professor de geografia em formação, optou por representar "Qfwfq" como um ser com feições masculinas, porém assexuado; da mesma forma

ParaOnde!?, Porto Alegre, v.12 n.2, p.96-106, 2019. http://seer.ufrgs.br/paraonde Edição Especial - III Colóquio de Pesquisadores em Geografia Física Ensino de Geografia 
representou Ayl como um ser claramente feminino, também assexuado. Esta representação cria identificação e empatia por parte do leitor.

Em linhas gerais Rodrigues (2015) seguiu as principais regras sobre a produção de uma narrativa em quadrinhos. Cada quadro foi a escolha de um momento no tempo. Segundo McCloud (1995), como qualquer narrativa pode ser dividida de maneira infinita (teoricamente), o artista gráfico pode optar por esticar um ou outro momento, e mesmo condensar outros numa só imagem. Na figura 1 e 2 estão reproduzidas, respectivamente a primeira e a última página do livreto criado.

Figura 1- Primeira página da História em Quadrinhos "Sem Cores".

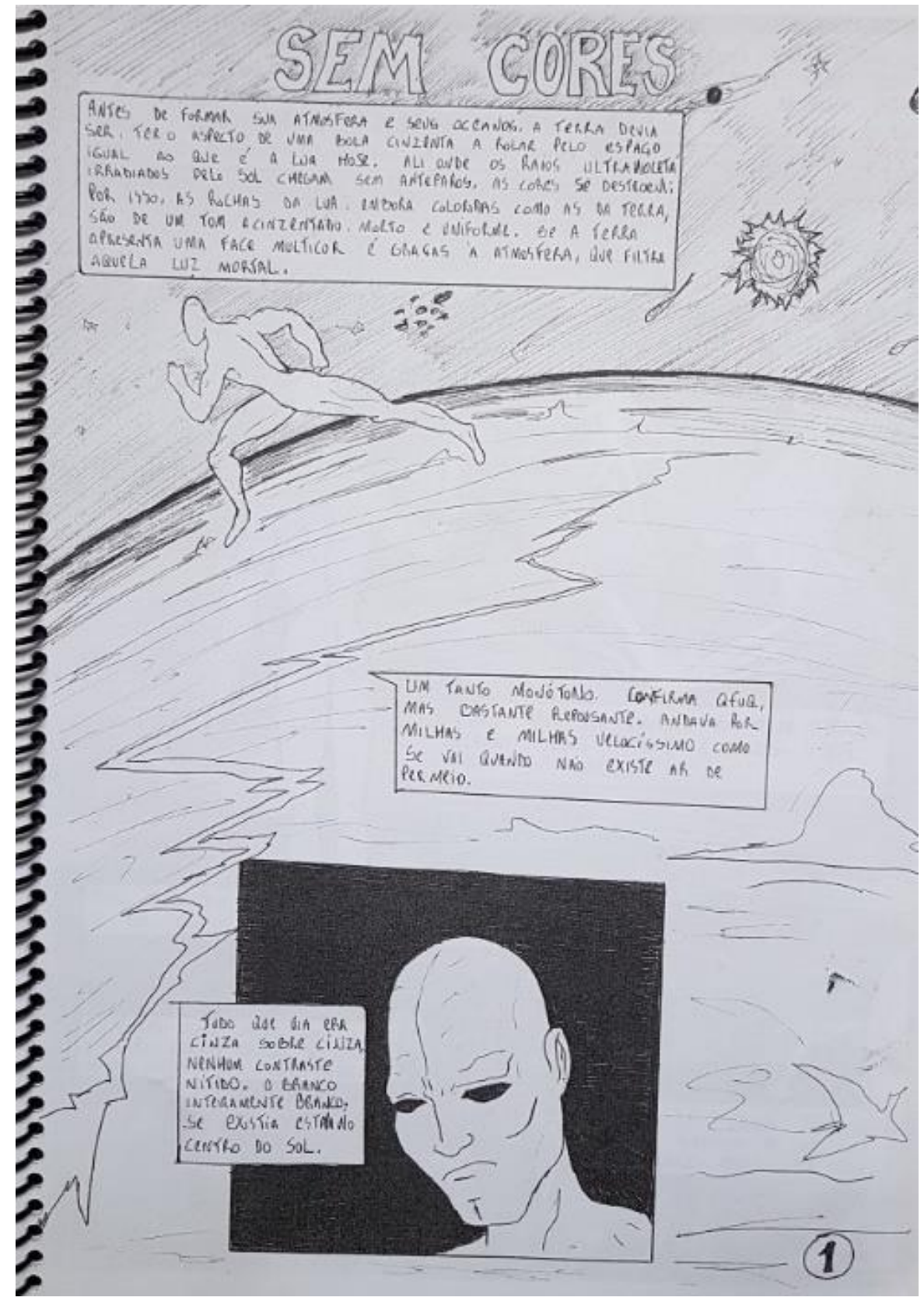

Fonte: Rodrigues, 2015.

ParaOnde!?, Porto Alegre, v.12 n.2, p.96-106, 2019. http://seer.ufrgs.br/paraonde Edição Especial - III Colóquio de Pesquisadores em Geografia Física Ensino de Geografia 
Figura 2- Última página da História em Quadrinhos "Sem Cores".

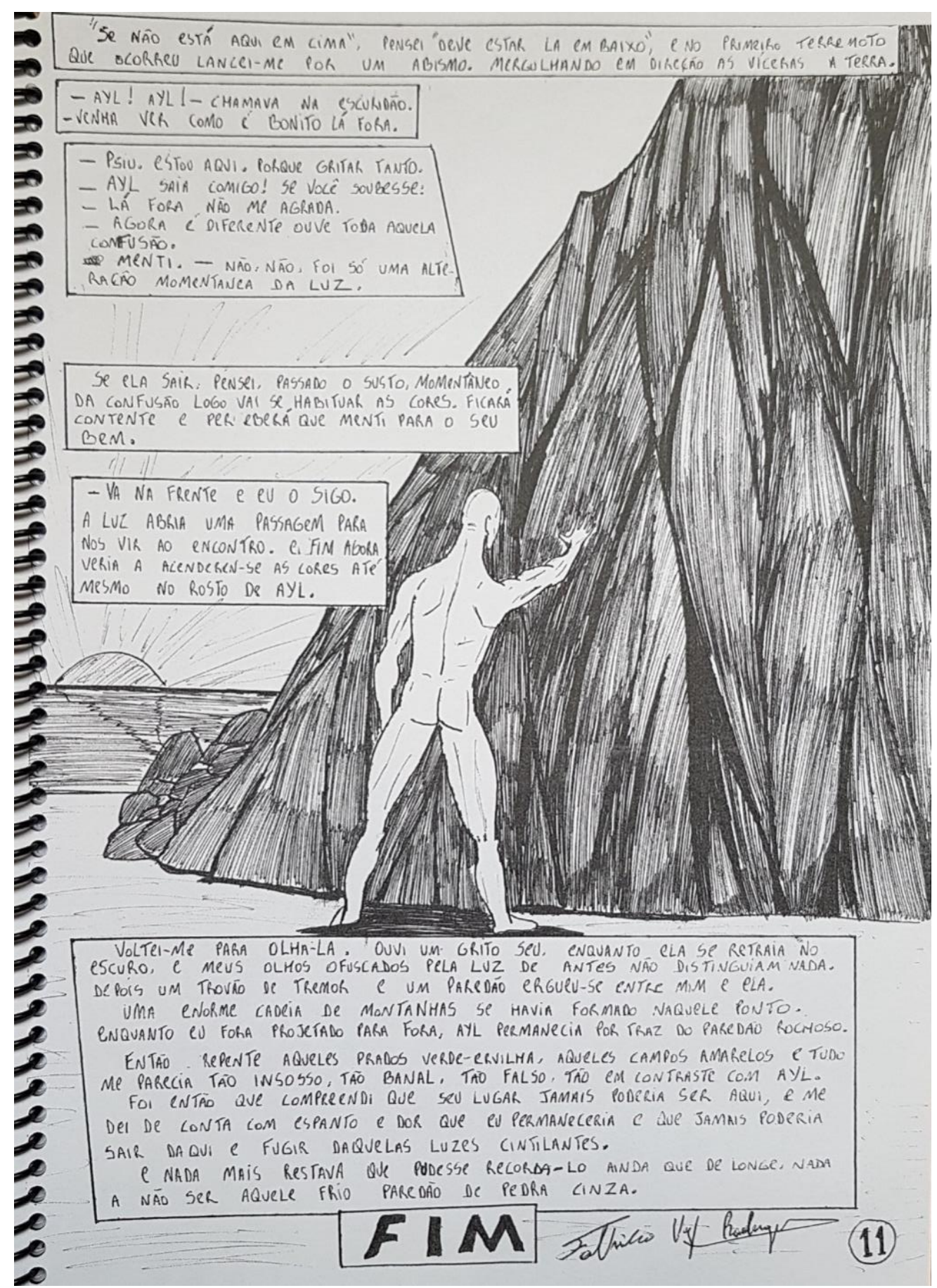

Fonte: Rodrigues, 2015.

Em cada quadro, os desenhos foram produzidos em branco e preto, com o uso de hachuras. Elas dão mais dinâmica ao desenho, quando usadas para atenuar áreas escuras demais, para marcar o impacto de algum objeto ou como sombra para dar força e expressão para os personagens e cenários e detalhar certas partes do traço (figura 3).

ParaOnde!?, Porto Alegre, v.12 n.2, p.96-106, 2019. http://seer.ufrgs.br/paraonde Edição Especial - III Colóquio de Pesquisadores em Geografia Física Ensino de Geografia 
Figura 3- Elementos usados para dar dinâmica ao desenho em visão panorâmica

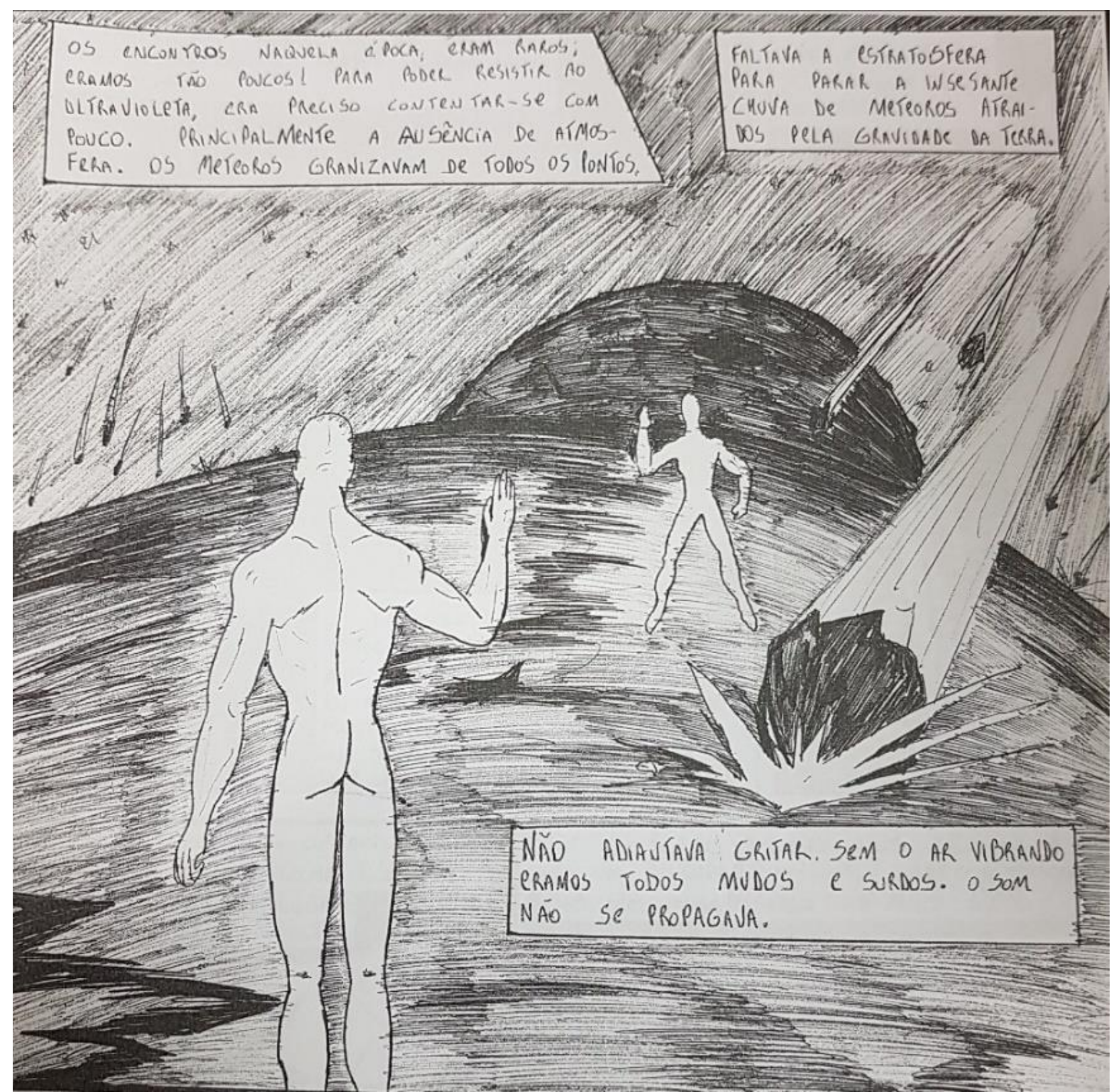

Fonte: Rodrigues, 2015.

Além disso, em cada quadro se define muito bem a relação do leitor com o objeto ou com o personagem. Segundo McCloud (1995), a proximidade (visão focal) ou distância (visão panorâmica) do enquadramento da cena definem quão próximo ou distante está o espectador-leitor. Enquanto a visão panorâmica (figura 3) dá pouca informação sobre a personalidade da personagem, mas explica o contexto, a proximidade mostra o estado de espírito da cena (figura 4) e a visão focal permite que se preste atenção às suas expressões faciais (figura 5).

ParaOnde!?, Porto Alegre, v.12 n.2, p.96-106, 2019. http://seer.ufrgs.br/paraonde Edição Especial - III Colóquio de Pesquisadores em Geografia Física Ensino de Geografia 
Figura 4- Vista de proximidade da cena

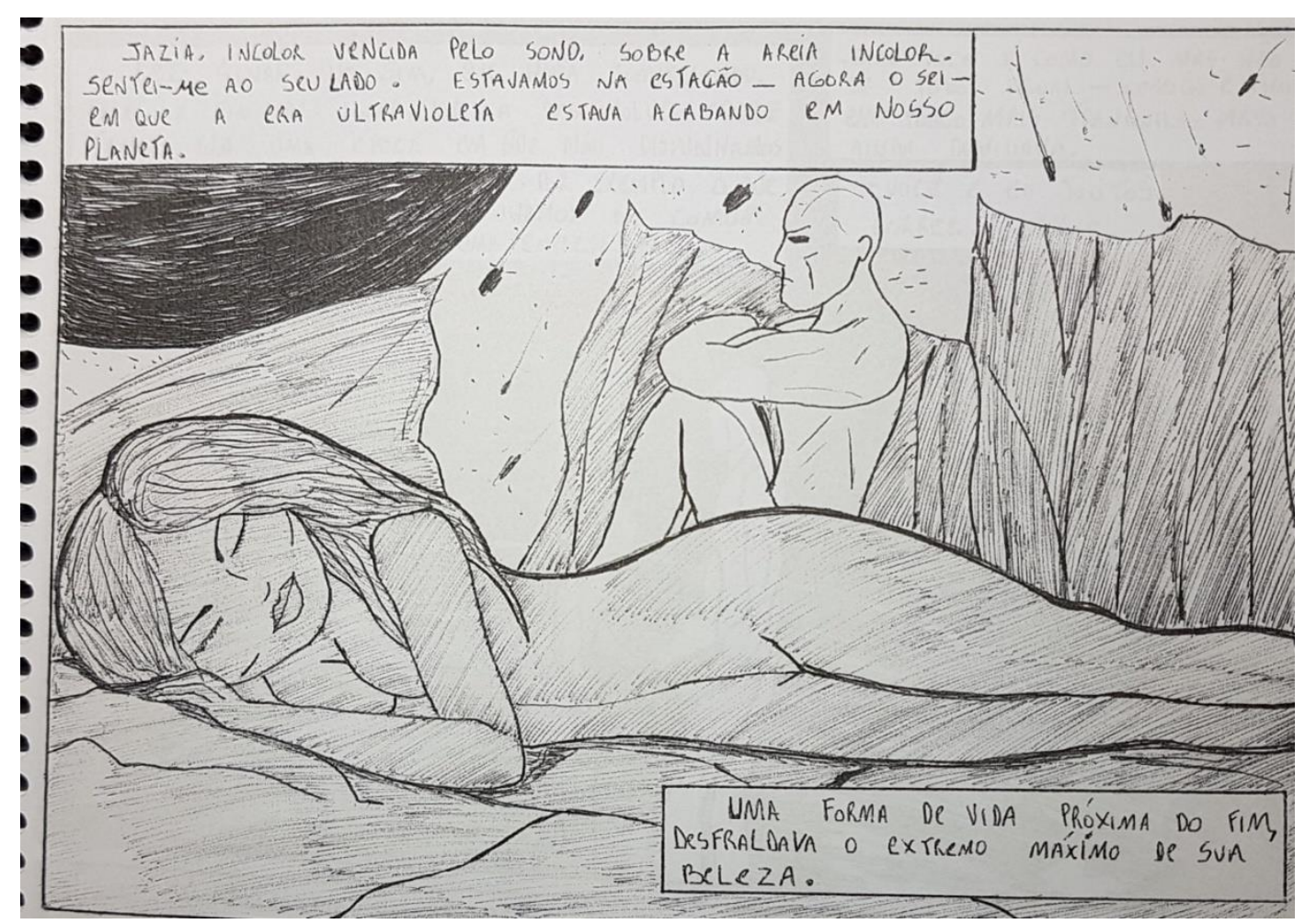

Fonte: Rodrigues, 2015.

Figura 5- Quadro em visão focal

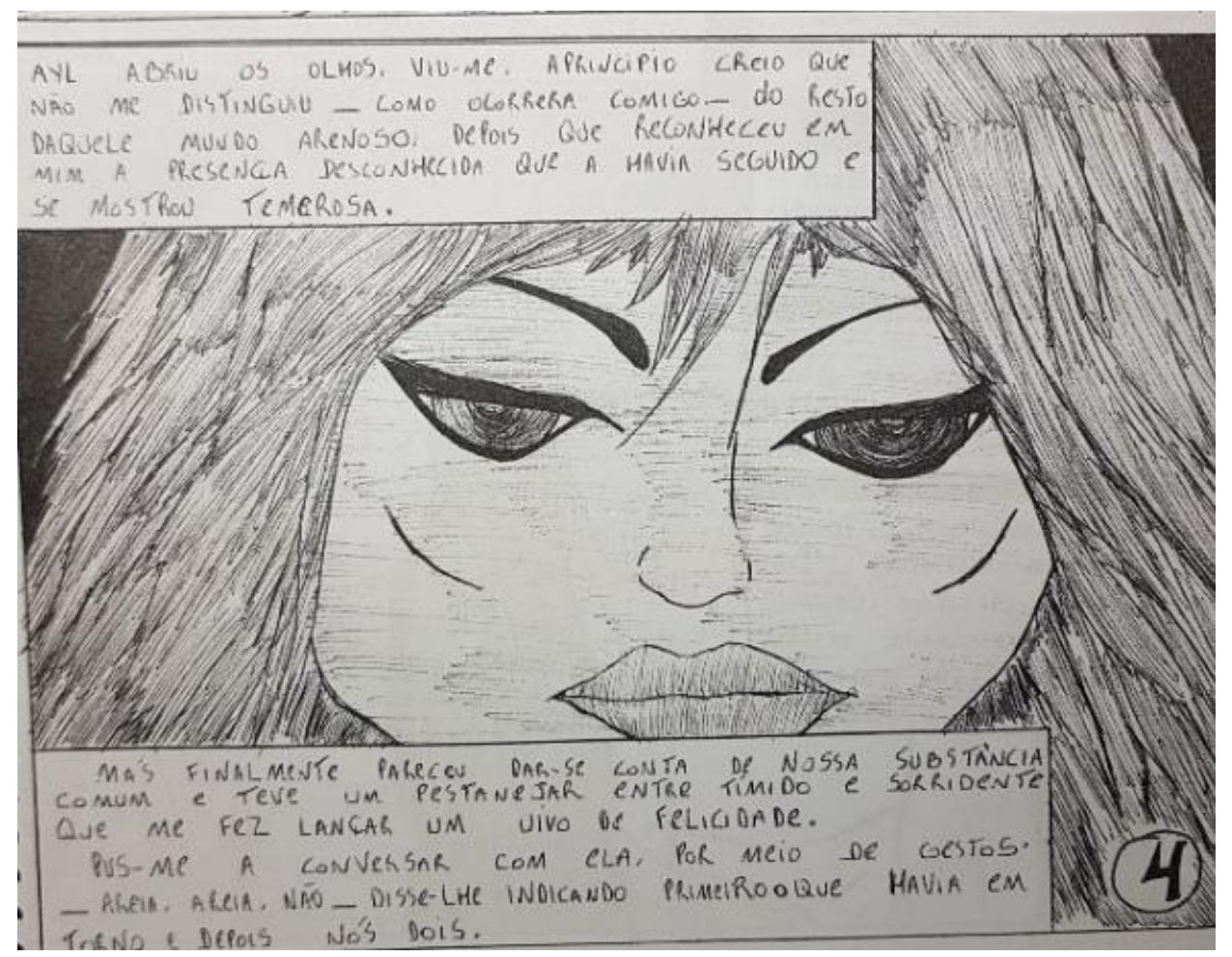

Fonte: Rodrigues, 2015.

ParaOnde!?, Porto Alegre, v.12 n.2, p.96-106, 2019. http://seer.ufrgs.br/paraonde Edição Especial - III Colóquio de Pesquisadores em Geografia Física Ensino de Geografia 
Rodrigues, portanto, se tornou um "leitor inspirado", o que se exemplifica através deste devaneio apresentado na forma de história em quadrinhos, na qual as virtualidades do texto se transformaram em visualidade, que incorpora os pressupostos científicos bem como a forma de ver e a experiência pessoal de vida do quadrinista.

\section{Considerações finais}

Muitas vezes se desconhece os talentos que há na sala de aula e acaba se premiando somente aqueles que escrevem bem ou os que se expressam bem verbalmente. Por outro lado, o nosso cotidiano e o cotidiano dos nossos alunos é cada vez mais visual; então, porque não incorporar os quadrinhos, o grafite e a fotografia nos processos de aprendizagem?

Apresentar a descrição das origens da atmosfera terrestre aos alunos do Ensino Fundamental ou Médio por um conto, por uma história em quadrinhos, ou provocando-os para que criem a sua própria sequência de quadrinhos a partir do roteiro proposto por Italo Calvino, nos parece mais eficaz do que aplicar questionários com respostas fechadas sobre a origem, composição e efeitos desta fina camada de gases que envolve a Terra.

Tal forma de apresentar o tema é mais apropriada, até porque existem lacunas no conhecimento científico sobre as origens da atmosfera terrestre. Aquilo que sabemos é pela associação de imagens que os cientistas criaram sobre este processo, baseando-se em evidências que a pesquisa foi colhendo. Desta forma, também a distância entre a ciência e a literatura é menor do que se supõe. Escreveu Calvino (1990, p.170): "A mente do poeta, bem como o espírito do cientista em certos momentos decisivos, funciona segundo um processo de associações de imagens que é o sistema mais rápido de coordenar e escolher entre as formas infinitas do possível e do impossível".

Trazer diferentes linguagens para as aulas, também na Universidade, é fundamental, uma vez que trabalhamos com futuros educadores. Neste mundo cada vez mais competitivo, globalizado e tecnológico, vemos a necessidade de Ihes contrapor uma visão que acolha também o subjetivo, o imaginário, para que, como afirma Perkoski (2015, p. 25), "[...] as gerações seguintes realizem a síntese dialética desses elementos opostos com o objetivo de tornar esse mundo um espaço melhor de convivência existencial", um mundo que tenha abertura para imaginação, memória, fantasias e devaneios.

Se não conseguimos convencer o leitor e fazer uso da literatura nas aulas de geografia, esperamos que, ao menos, tenhamos o provocado a ler os contos de Italo Calvino reunidos em "As Cosmicômicas".

\section{Referências}

CALVINO, Italo.Seis propostas para o próximo milênio: lições americanas.

ParaOnde!?, Porto Alegre, v.12 n.2, p.96-106, 2019. http://seer.ufrgs.br/paraonde Edição Especial - III Colóquio de Pesquisadores em Geografia Física Ensino de Geografia 
Tradução de Ivo Barroso. São Paulo: Companhia das Letras, 1990.

CALVINO, Italo. As cosmicômicas. Tradução Ivo Barroso. São Paulo: Companhia das Letras, 1992. 155p. p. 51-61.

DIAS, Juliana M. T. Infância em Gaston Bachelard: Reflexões sobre o Ensino de Geografia. Revista da Abordagem Gestáltica - Phenomenological Studies - XXII (2): 162-170, jul-dez, 2016.

FERRAZ, Bruna Fontes. 0 universo em um livro: as Cosmicômicas, de Italo Calvino. 2013. Dissertação de mestrado. Programa de Pós-Graduação em Letras da Universidade Federal de Minas Gerais. Belo Horizonte, 2013. 112 p.

McCLOUD, Scott. Desvendando os quadrinhos. Tradução Helcio de Carvalho e Marisa do Nascimento Paro. São Paulo: Makron Books, 1995.

PERKOSKI, Norberto. Quarenta anos da revista Signo, dezessete anos dos Encontros com a Poesia. Signo. Santa Cruz do Sul, v. 40, n. 68, p.20-30, jan./jun. 2015. Disponível em:

https://online.unisc.br/seer/index.php/signo/article/view/6165>. Acesso em: 22 abril 2018.

RODRIGUES, Fabrício Vaz. Sem Cores - adaptado aos quadrinhos. (Manuscrito) Rio Grande, 2015. Trabalho acadêmico.

VILAROUCA, C. G. Ciência, literatura e visibilidade em As Cosmicômicas. Revista de Letras, São Paulo, v.50, n.2, p.363-374, jul./dez., 2010. 